\title{
Borehole logs from the Precambrian basement on Bornholm, eastern Denmark: geology and groundwater flow
}

\author{
Peter Gravesen, Bertel Nilsson, Per Rasmussen and Stig A. Schack Pedersen
}

Bornholm is situated in the Sorgenfrei-Tornquist Zone that separates the North-West European Craton from the Baltic Shield and the East European Platform (Fig.1). The Precambrian basement of northern and eastern Bornholm consists of different granitic and gneissic Mesoproterozoic rocks that are dated to $c .1455 \mathrm{Ma}$ (Waight et al. 2012). It appears from the age data that granitic magmatism, deformation and metamorphism occurred over a relatively short time period. The rocks contain abundant pegmatite and aplite bodies. More than 250 mafic dykes occur. The dykes were intruded during three Precambrian events at c. $1326 \mathrm{Ma}, 1220 \mathrm{Ma}, 950 \mathrm{Ma}$ and during a Permian event at c. $300 \mathrm{Ma}$ (Holm et al. 2010).

The present study focuses on the Østermarie-Paradisbakke area north of Paradisbakkerne and deals with the Paradisbakke migmatite and part of the Bornholm gneiss. The aim of the study was to map the distribution of fractures in the rocks and determine the groundwater flow in these low-permeability rocks using outcrop data and borehole logs.

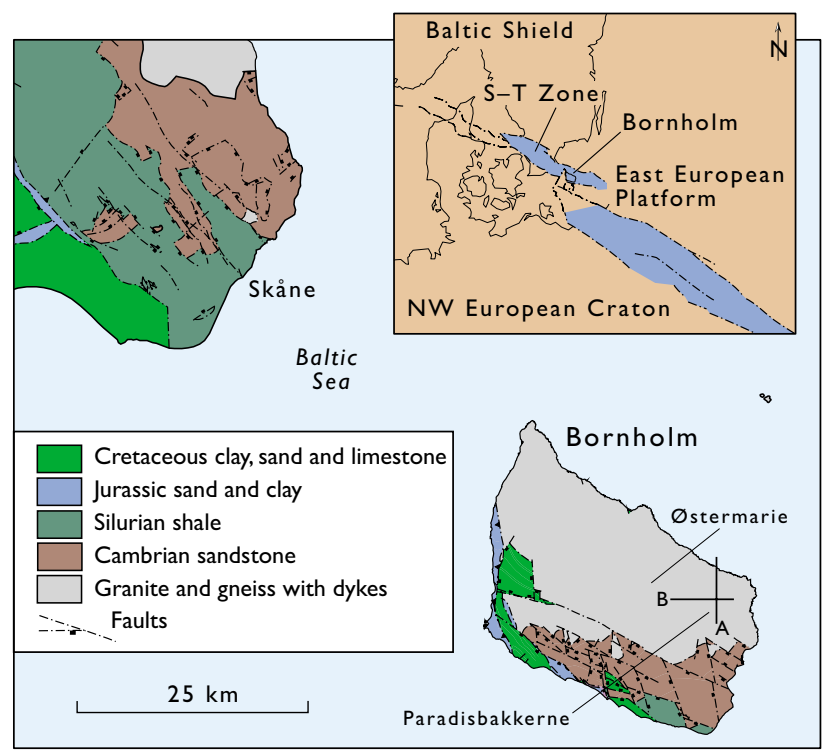

Fig. 1. Geological map of Bornholm and Skåne in southern Scandinavia. The location of the two cross-sections shown in Fig. 4 is indicated. Inset: Bornholm's location in the Sorgenfri-Tornquist Zone (S-T Zone; from Graversen 2009).
The survey was part of an investigation of potential areas for disposal of radioactive waste from the Research Centre Risø area (Gravesen et al. 2011a, b, 2012, 2013).

\section{Rocks, fractures and groundwater}

The two types of crystalline basement rocks in the study area show similar mineralogy and are dominated by K-feldspar (35-38\%), quartz (23-30\%), plagioclase (22-25\%) and hornblende (11-17\%); biotite and other minerals also occur (Micheelsen 1961). The Bornholm gneiss is medium-grained and grey or reddish grey. The fine- to medium-grained Paradisbakke migmatite consists of almost parallel, light grey

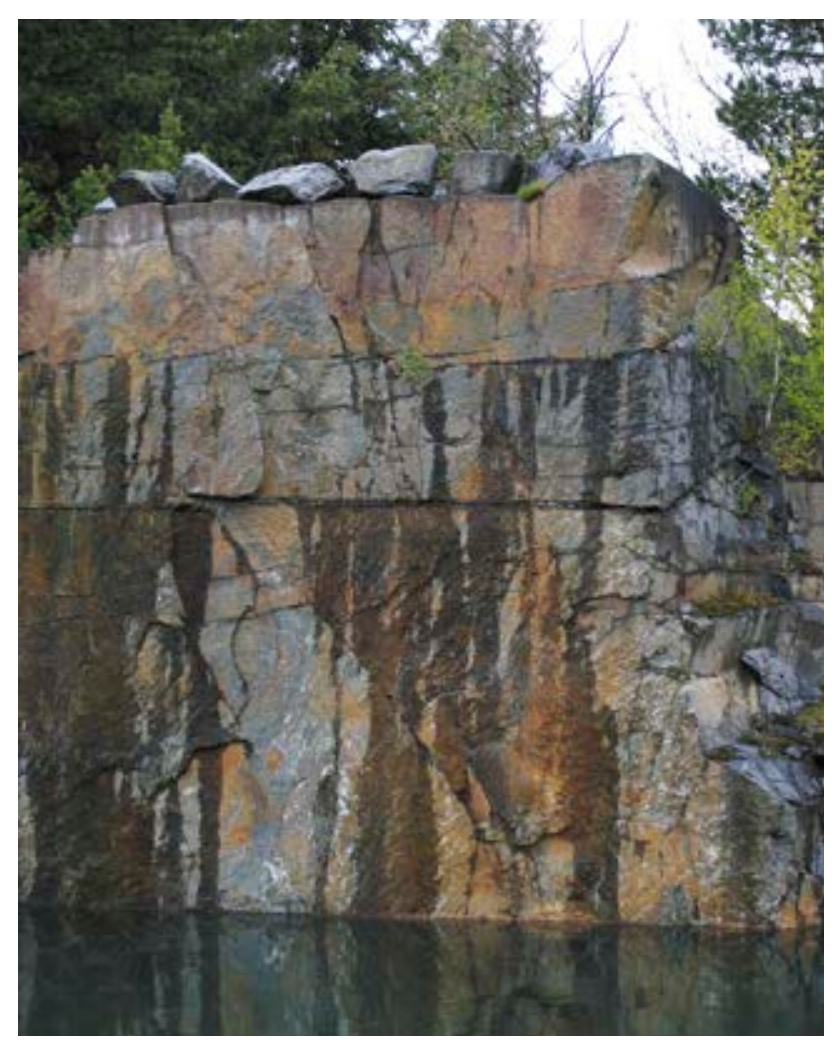

Fig. 2. Paradisbakke migmatite in Præstebo quarry at the northern rim of Paradisbakkerne. Horizontal and vertical fractures are common whereas oblique fractures are rare. The height of the outcrop is $c .12 \mathrm{~m}$. 
granitic quartz-feldspar veins in a darker matrix. Both rocks contain pegmatite bodies and are cut by thin NNE-SSWoriented dykes that were intruded c. $1220 \mathrm{Ma}$ ago. Minor bodies of reddish grey granite are also present.

The rocks are cut by four fracture systems, which can be observed in quarries with Paradisbakke migmatite along the northern rim of Paradisbakkerne (von Bubnoff 1942; Fig. 2). After deformation and cooling in the Precambrian, large tectonic faults and fractures and minor vertical fractures were formed.

The main fracture system in the area has an NNE-SSW orientation, corresponding to the direction of the mafic dykes (Micheelsen 1961). Large linear, fault-controlled valleys are found in Paradisbakkerne and in the western part of the Precambrian basement on Bornholm, but such valleys are absent in the study area. However, small vertical fractures with the same orientation are seen in outcrops.
A second ESE-WNW-oriented verical tectonic fracture system that shows the same orientation as Palaeozoic faults was probably formed during a main phase of wrench faulting in the Sorgenfrei-Tornquist zone in the Late Palaeozoic or later (Graversen 2009). Zones of $4.5 \mathrm{~m}$ thickness contain thin fractures with centimetre-sized spacing, while single fractures can have up to $5 \mathrm{~m}$ spacing. Small faults with slickensides are present and show that some horizontal movement has occurred. In addition to the vertical or subvertical fractures, rare occurrences of oblique fractures and conjugate fracture sets are also found.

A third system of horizontal fractures (sheet jointing) at levels from $25 \mathrm{~m}$ to $100 \mathrm{~m}$ depth was probably formed by load release when an overburden of supposed younger deposits, probably of Cambrian to Quaternary age, was eroded and removed (Spencer 1969). We assume that the spacing

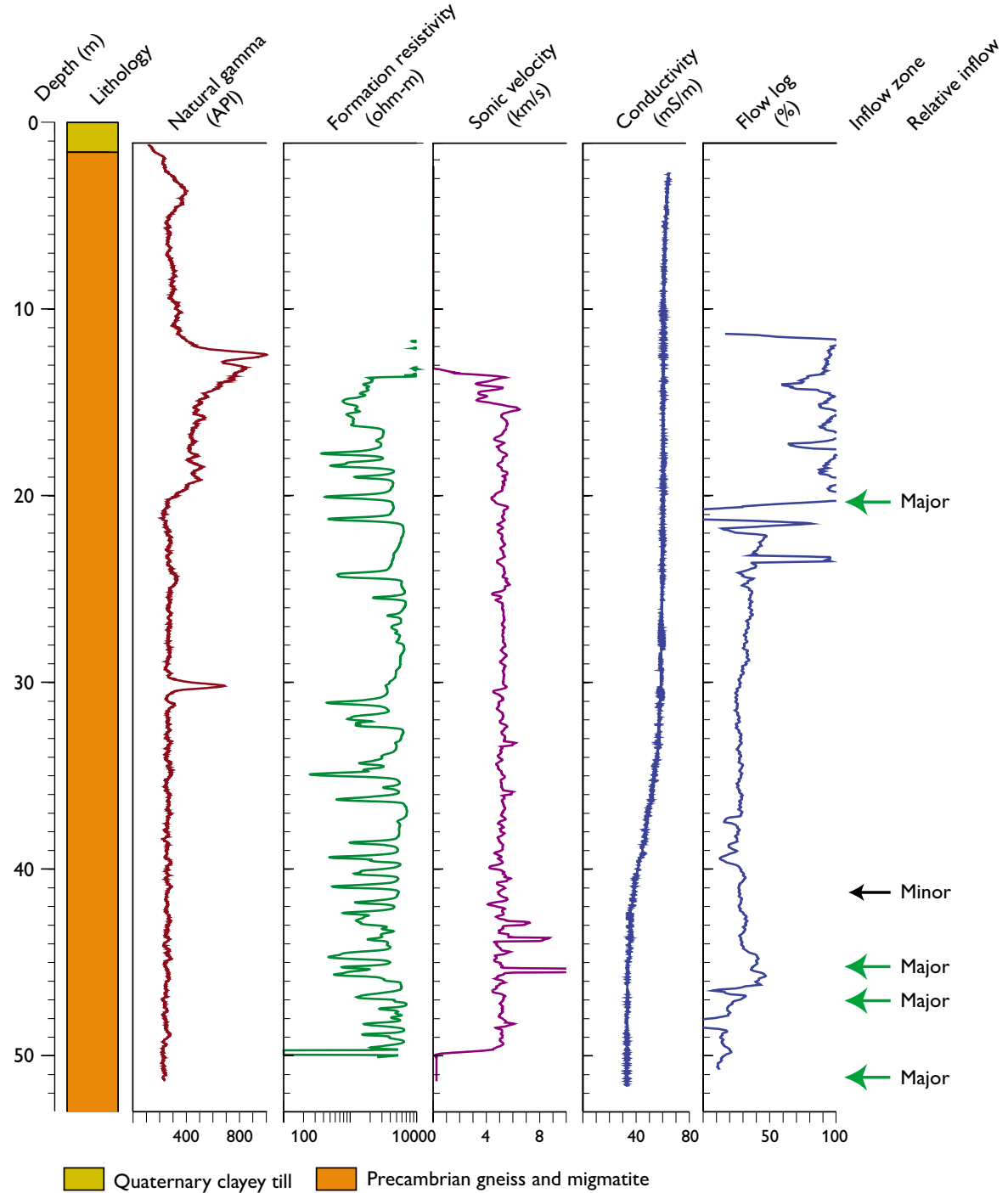

Fig. 3. Lithology and logs in borehole DGU no. 247.458. The flow-log data were acquired at a pumping rate of $1.3 \mathrm{~m}^{3} \mathrm{~h}^{-1}$. API: American Petroleum Institute units. 

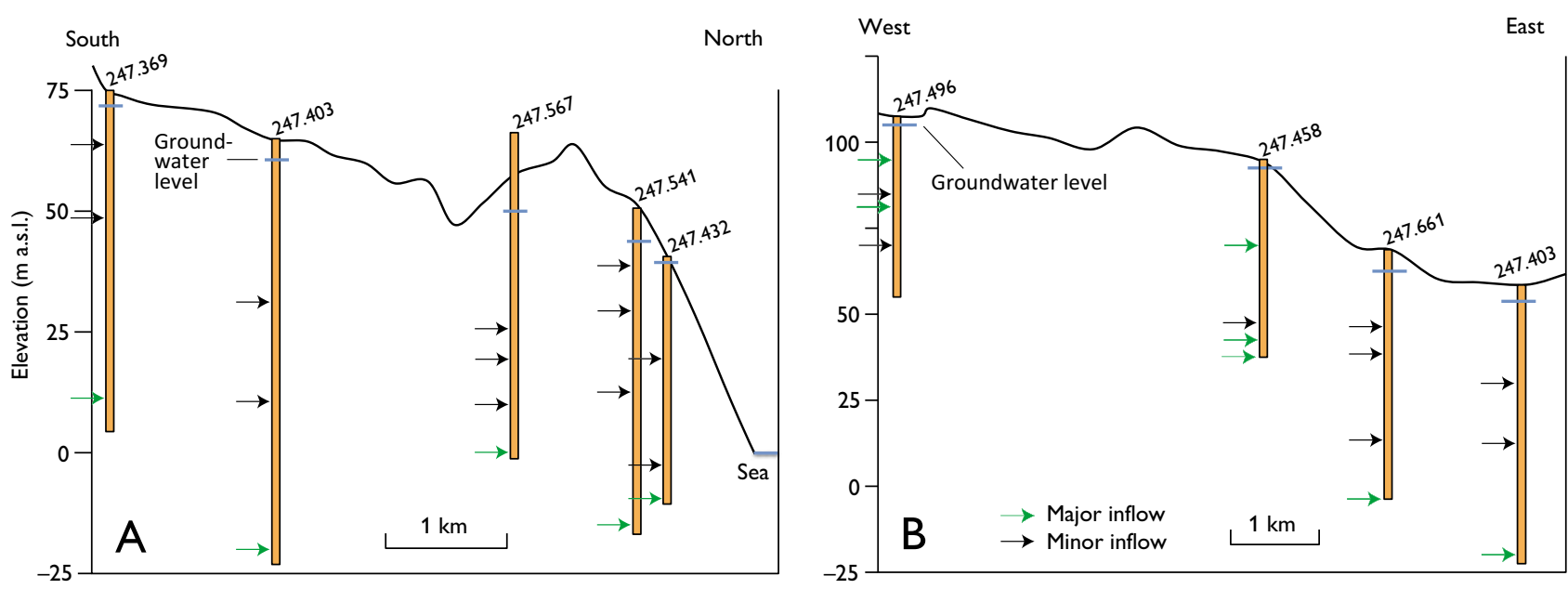

Fig. 4. Two cross sections through the logged boreholes. For location see Fig. 1. Note different horizontal and vertical scales.

between the fractures increases downwards, because this is seen in quarries.

A fourth fracture system consists of horizontal fractures near the ground surface with a spacing of 1-2 $\mathrm{m}$, which also increases downwards. Crushed rocks with blocky structures also occur. This system may have been formed by glaciers during the Quaternary.

The lower limit of the fractures is unknown but some horizontal fractures are found at $90 \mathrm{~m}$ below the ground surface. This means that water flow in vertical fractures that cross-cut the deep horizontal fractures can supply the deep fracture system with groundwater from above.

The rocks in the area are slightly weathered and Fe-containing minerals are oxidised to yellow- brown clayey, Fe-rich deposits on some fracture surfaces. Such deposits may prevent water flow in some of the fractures. Most of the area is covered by a clayey till up to $6 \mathrm{~m}$ thick.

The groundwater reservoir is characterised by a network of vertical to subvertical and horizontal to subhorizontal fractures. Surface water is mainly transported to the groundwater zone in the vertical fractures and the groundwater can be transported over long distances in the horizontal fractures. It is difficult to map the subsurface fractures but data from borehole logs can contribute to our understanding of the network. Normally the groundwater table is found a few metres below the ground surface but pumping will often lower the groundwater table because the storage capacity in the reservoir is small. The yield of boreholes in basement rocks on Bornholm is commonly low, but boreholes supplying Østermarie waterworks show high yields because of fracture systems in the rocks in this area.

\section{Borehole logs}

Eight private water boreholes in the study area were investigated by geophysical wireline logging. The water pump was removed in the morning and re-installed in the late afternoon after logging. The following geophysical parametres were measured: natural gamma radiation, formation resistivity, sonic velocity, conductivity and impeller flow. Conductivity and flow log data were acquired during groundwater pumping from the borehole. Natural gamma, resistivity and sonic velocity logs provide information on lithological variation in the borehole. The conductivity log gives information about groundwater chemistry and under certain conditions also provides information on groundwater inflow zones. The flow $\log$ measures the vertical flow velocity in the borehole. Changes in flow velocity during pumping indicate groundwater inflow zones at specific depths or depth intervals in the borehole.

\section{Results}

The results from the logging of borehole DGU no. 247.458 are shown in Fig. 3 and two constructed geological sections through the study area are shown in Fig. 4. In the $c .5 \mathrm{~km}$ long north-south section, the fracture inflow into four boreholes is shown (Fig. 4A). The depths of water flow in the basement rocks indicate the location of fractures and the inflow is evaluated semi-quantitatively as 'major' or 'minor' in each borehole. 'Major' indicates that the fracture inflow contributes a large part of the total inflow whereas 'minor' indicates only a minor contribution. 'Major' inflows are interpreted from the flow $\log$ where an increase in the flow $\log (\%)$ occurs, measured from the bottom towards the top of the borehole. 'Minor' inflows are interpreted from the conductivity log where 
changes in conductivity appear. The conductivity log can be more sensitive to minor influx zones than the flow log. It is relevant to compare the boreholes because they have the same low specific yield $\left(0.05-0.22 \mathrm{~m}^{3} / \mathrm{h}^{-1}\right)$. Figure 4 shows fracture inflow at four different depth intervals. Major inflow is registered near the bottom of the boreholes and minor fracture inflow is seen closer to the surface. The groundwater table is situated a few metres below the surface in all boreholes.

It is not possible to directly determine the orientation of the fractures, but fractures that are found at the same level, at c. 10 to $12 \mathrm{~m}$ a.s.l., are likely to be horizontal or subhorizontal and hydraulically connected.

In the $c .8 \mathrm{~km}$ long west-east section, fracture inflow is registered between $c .100 \mathrm{~m}$ a.s.l. and $25 \mathrm{~m}$ b.s.l. (Fig. 4B). Borehole DGU no. 247.496 at Østermarie waterworks is included in this section (Rasmussen et al. 2007). Inflow is seen in all boreholes but the largest inflow is found at the bottom of borehole DGU no. 247.403. Several important waterbearing fracture zones are found in the waterworks borehole. The fractures occur at shallower depths at at least four levels.

The results from the logging survey appear to confirm the occurrence of important fracture systems at depth. Fractures are located at different levels. Horizontal fracture systems seen over a large area are found at $10-12 \mathrm{~m}$ a.s.l. and a similar system occurs at c. $20 \mathrm{~m}$ b.s.l. Several smaller fracture systems without large water flow also occur. The most important and largest fracture system is found at $90 \mathrm{~m}$ below the surface, usually at the bottom of the boreholes. As mentioned above we cannot determine the orientation of the fractures from the borehole log survey, but the structural model indicates major elements of the fracture systems. The horizontal fracture spacing apparently increases with depth, but it is still posssible to find fracture systems with major water flow if they are connected to other vertical and horizontal fractures.

\section{Conclusions}

The conclusions of the investigations are as follows:

1. The logging of the boreholes shows that fracture systems occur in all of them.

2. The fractures occur down to at least $90 \mathrm{~m}$ below the surface, and flow logging documents the occurrence of groundwater flow down to this depth. The downward transport of surface water to the horizontal fractures may be via vertical fractures to at least the same depth.
3. Horizontal fractures are found at $10-12 \mathrm{~m}$ a.s.l. and at $20 \mathrm{~m}$ b.s.l. The fractures appear to be connected over kilometre-long distances.

\section{Acknowledgements}

The Danish Parliament is thanked for financial support. We are grateful to local landowners that gave us permission to log their private boreholes.

\section{References}

Graversen, O. 2009: Structural analysis of superposed fault systems of the Bornholm horst block, Tornquist Zone, Denmark. Bulletin of the Geological Society of Denmark 57, 25-49.

Gravesen, P., Nilsson, B., Pedersen, S.A.S. \& Binderup, M. 2011a: Lowand intermediate level radioactive waste from Risø, Denmark. Location studies for potential disposal areas. Report no. 4. Characterisation and description of areas Bornholm. Danmarks og Grønlands Geologiske Undersøgelse Rapport 2011/44, 85 pp.

Gravesen, P., Binderup, M., Nilsson, B. \& Pedersen, S.A.S. 2011b: Geological characterisation of potential disposal areas for radioactive waste from Risø, Denmark. Geological Survey of Denmark and Greenland Bulletin 23, 21-24.

Gravesen, P., Nilsson, B., Binderup, M. Larsen, T. \& Pedersen, S.A.S. 2012: Lav- og mellem radioaktivt affald fra Risø, Danmark. Omegnsstudier. Rapport nr. 1. Område Østermarie-Paradisbakkerne, Bornholms Regionskommune. Danmarks og Grønlands Geologiske Undersøgelse Rapport 2012/123, 100 pp.

Gravesen, P., Nilsson, B., Binderup, M., Larsen, T.B. \& Pedersen, S.A.S. 2013: Geology, seismic activity and groundwater conditions at six potential disposal sites for radioactive waste from Risø, Denmark. Geological Survey of Danmark and Greenland Bulletin 28, 13-16.

Holm, P.M., Pedersen, L.E. \& Højsteen, B. 2010: Geochemistry and petrology of mafic Proterozoic and Permian dykes on Bornholm, Denmark: four episodes of magmatism on the margin of the Baltic Shield. Bulletin of the Geological Society of Denmark 58, 35-65.

Micheelsen, H. 1961: Bornholms grundfjæld. Meddelelser fra Dansk Geologisk Forening 14, 308-349.

Rasmussen, P., Klitten, K., Nielsen, S. \& Jensen, P. 2007: Bornholms Regionskommune. Logging og vandkemi i vandforsyningsboringer, 2006. Danmarks og Grønlands Geologiske Undersøgelse Rapport 2007/36, $91 \mathrm{pp}$.

Spencer, E.W. 1969: Introduction to the structure of the Earth, 597 pp. New York: McGraw-Hill.

von Bubnoff, S. 1942: Beiträge zur Tektonik des skandinavischen Südrandes. 2. Die älteren Granite Bornholms im Rahmen der svekofennidischen Tektogenese. Neues Jahrbuch für Mineralogie, Geologie und Paläontologie, Beilagen-Band 87, 277-396.

Waight, T., Frei, D. \& Storey, M. 2012: Geochronological constraints on granitic magmatism, deformation, cooling and uplift on Bornholm, Denmark. Bulletin of the Geological Society of Denmark 60, 23-46. 